\title{
When Do Religious Leaders Support Faith-Based Violence? Evidence from a Survey Poll in South Sudan
}

\author{
Matthias Basedau ${ }^{1,2}$ and Carlo Koos'
}

\begin{abstract}
Religion has increasingly become important in conflicts worldwide. Religious leaders may play a key role in mobilizing believers as they can call for peace or instigate violence. But what makes religious leaders support peace or promote violence? Drawing on a survey poll of 102 religious leaders in Juba, South Sudan, this paper represents virtually the first attempt to study the correlates of pro-violence opinions of religious elites in a more quantitative manner in a developing country. The paper analyzes when and why some religious leaders support faith-based violence while others do not. Employing a unique combination of innovative measures, our results have many implications for mobilization processes. We find that leaders' support for faith-based violence is largely independent of individual demographic or personal determinants but is closely related to religious attitudes. Tolerance toward other faiths and secularism reduce pro-violence attitudes. Muslims seem to be more ready to support faith-based violence, probably given their minority status and other peculiarities of Islam in (South) Sudan. Surprisingly, interreligious activities do not reduce support for violence but increase appreciation for peaceful protest. Generally, determinants of peaceful protest substantially differ, suggesting that any support for violence follows its own distinct logic.
\end{abstract}

\section{Keywords}

religion and conflict, African politics, Sudan, elite opinion

\section{Introduction}

"Deus lo vult," Latin for "God wills it," were the words with which Pope Urban II called for the First Crusade at the Council of Clermont in 1095 (e.g., Horowitz 2009; Latham 2011). The bloody Crusades and many other faithdriven violent incidents demonstrate, to this day, the crucial role of religious leaders in many conflicts. Besides religious structures, ideas, and institutions, religious leaders play a key role in mobilizing religious groups (e.g., Fox 2013; Toft 2007). Given their legitimacy, credibility, and influence with many followers, religious leaders often command huge resources for mobilization (Fox 2013, 85-88) and may be the crucial difference that tips the balance in the "ambivalence of the sacred" (Appleby 2000). They can either call for peace or instigate violence. Recent empirical evidence suggests that pro-violence discourse by religious leaders contributes to the escalation of religious conflict (Basedau, Pfeiffer, and Vüllers 2014).

But what makes religious leaders either support peace or promote violence? Alongside many case study-oriented works, the more systematic literature on religious leaders has stressed the role of competition between leaders that result in outbidding processes that in turn generate extremism (De Juan 2009; Toft 2007). Other scholars have focused on group differences and social deprivations on which religious or other types of leader can capitalize on (Canetti et al. 2010; Hauk and Mueller 2015; Trejo 2009). Sociological and psychological survey-based research on why people generally countenance violence points to demographic variables such as age, gender, and education, or to the individual's personal experiences with violence (e.g., Black et al. 2010). However, such personal preferences and experiences have almost never been tested as alternative explanations for the chosen attitudes of religious leaders. Research on the determinants of religious leaders' attitudes toward violence has almost never used survey polls. Survey-based work on the effects of religious attitudes typically deals with ordinary believers only, covers few attitudes, and uses political intolerance

'GIGA German Institute of Global and Area Studies, Hamburg, Germany

${ }^{2}$ Peace Research Institute Oslo (PRIO), Oslo, Norway

\section{Corresponding Author:}

Matthias Basedau, GIGA German Institute of Global and Area Studies, Neuer Jungfernstieg 2I, 20354 Hamburg, Germany.

Email: Matthias.basedau@giga-hamburg.de 
as the dependent variable rather than violence (e.g., Eisenstein 2006).

Drawing on a survey poll of 102 religious leaders in Juba, South Sudan, this paper aims to contribute to the filling of this knowledge gap. This article provides the first attempt to study the attitudes of religious leaders toward violence based on an opinion poll in a developing country. Measured as the sanctioning of riots as a reaction to an offense to Mohammed and/or Jesus, this paper analyzes when and why some religious leaders are liable to support faith-based violence while others are not. The paper looks not only at classical determinants of support for violence such as age, gender, education, and previous personal experiences with violence, but also at a huge number of pertinent religious attitudes and behaviors such as tolerance toward other faiths, threat perceptions vis-à-vis other groups, and interreligious activities.

Results suggest that support for faith-based violence is largely independent from individual demographic determinants but is closely related to one's other religious attitudes. Those leaders who embrace secularism and are tolerant toward other faiths reject religion-based violence. The only exception in biographical terms is a Muslim identity of leaders. Given the proximity of radical Islamism in neighboring (North) Sudan and being a minority in the sample and in South Sudan, Muslims seem to more readily accept faith-based violence-however, they also have empathy for the riots of Christians and not just those of Muslims. Surprisingly, interreligious activities do not reduce support for violence although they do increase understanding for peaceful protest. We generally find evidence that the support of peaceful protests follows a different logic than for violent ones. A preliminary comparison with laymen suggests that the attitudes of leaders and ordinary believers are not the same.

Although we cannot generalize our results beyond the case of South Sudan, we believe that they are important for the link between religion and conflict in general. This paper is the first that systematically employs a combination of innovative quantitative measures for a wide range of relevant religious attitudes of religious leaders-not just believers - in the context of a developing country.

Our study also matters for the study of conflict in general. Recent empirical evidence suggests that religion plays a substantial role in a good share of conflicts (e.g., Fox 2004; Svensson 2007; Toft 2007). Between 1990 and 2010, more than 57 percent of armed conflicts in developing countries had religious overtones, that is, these conflicts were fought between different religious groups and/or the warring factions differed by theological claims (Basedau, Pfeiffer, and Vüllers 2014).

Our findings are also important for processes of political mobilization in general (Fox 2013, 84). Differences in the logic of peaceful and violent protest as well as the relationship between leaders and followers (e.g., Djupe and Gilbert 2003) matter well beyond the relationship of religion and violence.

\section{Literature Review}

The determinants of religious leaders' attitudes toward violence are derived from at least three strands of literature. First, we look at the link between religion and conflict - including the role of religious leaders therein. We then turn to those works that have attempted to explain why religious leaders support or call for violence. Finally, we take a look at what is known about why people in general, and not just leaders, are liable to engage in or support violence.

\section{Religion and Conflict}

Since the terrorist attacks of September 11, 2001, the link between religion and violent conflict has attracted increasing scholarly attention (e.g., Toft, Philpott, and Shah 2011). A growing body of literature has since emerged, mainly investigating religion as a potential cause of violence. Almost all works adopt the idea that a number of different aspects of religion ${ }^{1}$ can create the necessary opportunity and/or motive to help overcome the collective action problems that are faced by those individuals trying to perpetrate organized violence (see, for example, Davies 1962; Gurr 1970; McAdam, Tarrow, and Tilly 2001).

Many quantitative works have investigated the effects of several different forms of religious diversity, such as fractionalization, polarization, and dominance (of one group). Empirical results have been mixed, however, and yielded no evidence of robust relationships-possibly with the exception of dominance, which more regularly seems to increase conflict risks (see, for example, Ellingsen 2000; Montalvo and Reynal-Querol 2005; Rummel 1997). Recent quantitative works have found evidence that civil war becomes more likely when religious cleavages run parallel to divides of income, geography, and religion (e.g., Gubler and Selway 2012). Akbaba and Taydas (2011) found that religious discrimination by the state against ethnoreligious minorities slightly increases the risk of violence (see also Fox, James, and Li 2009).

While many case studies show that religious leaders can indeed instigate violence, as exemplified by Pope Urban II's call in 1095, there have been to date only a few systematic opinion-based studies that have tested this relationship directly. In a study on political violence perpetrated by Jews and Muslims in Israel, Canetti et al. (2010) found that relative economic and political deprivation results in support for violence only when religious 
leaders provide an inflammatory interpretation of these deprivations. In line with this finding, calls for violence might generally increase the risk of widespread conflict breaking out (Horowitz 2009; Juergensmeyer 2008).

\section{Determinants of Religious Leaders' Attitudes toward Violence}

Research on why religious leaders favor either violence or peace in a given situation thus far has mainly relied on qualitative works. Frequently, it is either religious extremism or peace activism - and not so much violence per se-that is explained through these studies (e.g., De Juan 2009; Toft 2007).

The basic finding thus far regarding the determinants of extremist or belligerent attitudes is that religious leaders do not support violence because of their core personal preferences. The literature suggests that religious leaders rather incite conflict - and later support violence - only when they feel threatened by competitors (e.g., De Juan 2009; Toft 2007; Trejo 2009). As religious leaders by nature try to preserve and also extend their influence, they would inevitably compete with other religious leaders for the backing of believers or political leaders when the need to do so arises. This competition for influence results in outbidding processes that generate extremist and aggressive views (see, for example, Toft 2007).

These processes do not occur out of context. Toft (2007) emphasizes the role of political leaders in them; according to her, close relations between political and religious leaders favor violence. Hauk and Mueller (2015) and Canetti et al. (2010), meanwhile, point to the significance of existing economic or other forms of marginalization. Existing group inequalities are an opportunity religious leaders can capitalize on to increase their support base. When marginalized themselves, religious leaders are also more prone to embrace extremist views.

All these works also stress the impact of context, but they do not focus on personal traits; in fact, the latter have almost never been tested with regard to religious leaders. As such, little work has investigated the determinants of religious leaders' attitudes toward violence in a quantitative manner and with individual level data. Existing survey-based works on the effects of religion on political attitudes almost exclusively focus on ordinary believers, typically employ only a small selection of religious attitudes, and often investigate several forms of political intolerance rather than the support of violence. These studies find that for the average Western respondent, religious fundamentalism is associated with political intolerance, ethnocentrism, and militarism, as well as with the preference for more violent solutions to political problems (e.g., Eisenstein 2006; Rothchild, Abdolhossein, and Pyszczynski 2009)
The (few) surveys on leaders have investigated the attitudes of protestant religious leaders toward the U.S. engagement in the Vietnam War (Quinley 1974) or toward domestic violence against women in the United States (e.g., Levitt and Ware 2006). To the best of our knowledge, however, there has thus far been only one systematic survey poll targeted at religious leaders in developing countries. Jeremy Menchik (2013) conducted a survey of 1,000 Islamic leaders in Indonesia. His questions, however, did not refer to attitudes directly related to violence but rather to religious tolerance; moreover, his results have not been published.

\section{General Determinants of Individual's Support for Violence}

Violence does not have its origins only in religion. The socio-psychological and criminological literature looks at a wide range of other reasons why individuals support or engage in violence (e.g., Black et al. 2010; Hirschi and Hindelang 1977; Bellair and McNulty 2009). Quantitative works on the topic are mainly based on surveys covering only youths and young adults. The most widely used indicator of violence is self-reported violent action itself, and not a propensity for violence per se.

Researchers usually cluster these variables by differentiating between demographic (e.g., age gender, race, socioeconomic status) and personal measures (e.g., family background, impulsivity). Robust correlates of violence are a number of demographic characteristics such as age, gender, and socioeconomic status (e.g., education, social status, occupation). Younger males from more disadvantaged social backgrounds are more prone to supporting violence.

Besides demography, one's specific personal life experience is also robustly linked to more violent behavior. The nature of one's family background, and especially prior exposure to violence within the family environment, increases the risk of an individual later becoming favorable to violence (e.g., Black et al. 2010). Lower levels of education and intelligence also increase the risk of an individual engaging in violent activities (e.g., Hirschi and Hindelang 1977). In addition, the neighborhood one inhabits, discrimination, gang membership, and the abuse of alcohol and other substances also count (Bellair and McNulty 2009). Another (classical) strand of the literature deals with authoritarianism and closed mindedness and how these traits relate to dogmatism and intolerance (Adorno et al. 1950; Rokeach 1960). Although these studies do not focus on violence, one can assume that intolerance and violence are closely related.

In sum, previous research has clearly underscored that religious leaders are important in the outbreak of religious and other forms of conflict. We have also seen that 
works that investigate the determinants of religious leaders' attitudes toward violence or actual violent behavior have almost never tested individual level data - despite opinion survey-based research having identified personal traits, attitudes, and experiences as important determinants thereof.

\section{Theoretical Argument and Hypotheses}

Theoretically, we combine two strands of the literature: research on the general individual determinants of violence and research on the determinants of pro-violence attitudes among religious leaders. As a theoretical starting point, we assume that religious leaders are not too different from ordinary human beings. As such, their attitudes toward violence will, either way, be no different from those of other individuals. We hence hypothesize that classical demographic and biographical characteristics will shape the likelihood of religious leaders supporting violence. Younger males are, accordingly, more prone to favor violence. Higher levels of education and having spent some time outside of one's own country will widen the individual's horizons and empathy with other beliefs, cultures, and nationalities. Better educated people usually tend to hold antiviolence norms and can anticipate better the harmful consequences of aggressive actions (e.g., Hirschi and Hindelang 1977). The contact hypothesis (Sherif et al. 1961) expects that being familiar with other cultures decreases the likelihood of conflict. Finally, one's personal experience with violence will also affect their attitude toward the use of faith-based forms of it. We follow here the findings from the literature that personal experience with violence will increase a propensity for it (e.g., Black et al. 2010). In sum, with regard to the demographic and biographical features of individuals, we hypothesize as follows:

Hypothesis 1 (H1; demography): Religious leaders will support violence more readily when they are (1) younger and (2) male.

Hypothesis 2 (H2; biography): Religious leaders will support violence more readily when they have (1) lower levels of education, (2) not spent time abroad, and (3) personally experienced violence themselves.

It may however also be true that religious leaders are special members of the community. They undergo specialized training in theological issues, they are probably more reflective individuals than the average citizen, and, arguably, faith plays a much bigger role in their lives than it does in those of ordinary people and laymen. In this context, it may become crucial what kind of attitudes these leaders hold vis-à-vis faith-related issues besides those on violence. Generally, we believe that more intolerant views with regard to other religious faiths or the order of the state will also be accompanied by greater support for violence in principle (see, for example, Adorno et al. 1950; Rothchild, Abdolhossein, and Pyszczynski 2009). Intolerant and more violencefavoring views can take several different forms. Rejecting a secular constitution may signify that a leader thinks that his (or her) faith is superior to other beliefs - or that nonreligious (atheist or agnostic) views are inferior. Threat perceptions vis-à-vis other (religious) groups may fuel greater support for violence as well. The individual who feels threatened is more likely to take up arms in what they believe is self-defense. In sum, we hypothesize that one or all of a number of religious attitudes increase the support for violence:

Hypothesis 3 (H3; religious attitudes): Religious leaders will support violence more readily when they hold other intolerant and hostile views on interreligious relations and other faiths such as (1) rejecting a secular constitution, (2) intolerance toward members of other faiths, or (3) threat perceptions vis-à-vis other groups.

Attitudes are different from experiences and behaviors. Drawing again on the "contact hypothesis" (Sherif et al. 1961), but directly related to interreligious activities and not just intercultural experience, many scholars and practitioners (e.g., Smock 2002) assume that religious leadersbeing probably no different from ordinary believers-will be less supportive of violence when they have had more prior experience and interaction with people from other denominations or generally view these activities positively. Such contact will undermine stereotypes and prejudices. Knowing people personally and being ready to cooperate with them make it less easy to countenance violence against them. We thus assume as follows:

Hypothesis 4 (H4; interreligious activity): Religious leaders will support violence more readily when they lack experience with and hold positive views of interreligious activities.

A final hypothesis deals with religious identity. It is, of course, politically sensitive to make assumptions about the role of one's Muslim identity in his or her relationship to violence. Generally, we are not in favor of an essentialist notion of Islam - or of any other religious tradition for that matter. Christianity, Islam, or any other religious belief - with the possible exception of Satanism - is not inherently either violent or peaceful. We believe rather that the use of religious ideas for violence or peace depends on specific social circumstances. When radical discourse and faith-based violence are more prevalent in a given country or community, the approval for those practices will increase. More precisely, these circumstances in 
South Sudan exist in the context of an Islamist regime in (Northern) Sudan. Many Muslim leaders in Southern Sudan have a Northern background - something also revealed by our own survey data. The Northern Sudanese government draws inspiration from extremist Islamism and has engaged in faith-based violence. One such pursuit has been the organization of violent riots, for instance, against the Danish Mohammed cartoons. Muslims also form a minority in South Sudan, possibly making them more sensitive to religious insults and/or threat perceptions. Many minorities radicalize under these circumstances. In sum, these considerations make us believe in the following hypothesis:

Hypothesis 5 (H5; religious identity): (South Sudanese) Muslim religious leaders will support riots more readily than other religious leaders.

\section{Data and Empirical Strategy}

\section{Religion and the Case of South Sudan}

The empirical basis of this study is a survey poll that was conducted in October 2012 in Juba, South Sudan. This study is not per se so much about South Sudan, which rather serves as an example for the relationship between religious leaders and their attitudes to violence in general.

However, we should give a brief overview of the role of religion in South Sudan and its relation to conflict there. Most South Sudanese people are Christians or adherents to African Traditional Religions (ATRs). It is perhaps a defining feature of religion in the country that these traditions often mix; South Sudanese Christendom is constituted by a syncretic Christianity. Muslims are a minority in the country. These individuals are overwhelmingly Sunni Muslim; many have a Northern background and have their roots in what is now (Northern) Sudan. The Pew Research Center (Pew Forum 2012) estimated that in 2010, 60.5 percent of the population were Christian, 32.9 percent were followers of ATR, and 6.2 percent were Muslim.

Neither South Sudan nor Juba is a hotspot of religious conflict. Faith-based violence has been minimal; religious leaders and organizations there have, rather, made efforts to address the various intercommunal conflicts that broke out (see Agwanda and Harris 2009; Breidlid and Stensland 2011) - such as between Nuer and Dinka. ${ }^{2}$

The rather moderate role of religion within South Sudan makes it particularly worthwhile to study the determinants of support for violence in this location-a place where religious radicalism is not a dominant force. Before its independence, however, South Sudan had a highly conflictive relationship with Northern Sudan in which the Christian-Animist Southern part faced off against the Muslim North. This conflict had pronounced religious overtones to it (see, for example, Toft 2007). Northern efforts to dominate South Sudan also included the imposition of Sharia law on the whole country. In the midst of the violence of the decade-long Northern aggression and the Southern upsurge, religion provided some sense and solace for the afflicted population. Beyond the spiritual refuge provided, the Christian churches were also among the few institutions to provide basic services such as health care, education, shelter, and food for the suffering population. The strong social role that the church played during the civil war has since persisted in South Sudan. Religion thus continues to be an integral part of daily life for the South Sudanese (Agwanda and Harris 2009).

In sum, we do not claim that South Sudan is a representative or "crucial" case for the study of the relationship between religion and violence. However, we argue that South Sudan is not a bad choice either. While the civil war in unified Sudan had strong religious overtones, we do not find an unusual amount of religious extremism in independent South Sudan. It thus represents rather a hard than an easy case for our hypotheses and might therefore be particularly suited to study the relationship.

\section{The Sample}

Juba is the capital of Africa's youngest independent state, South Sudan, having an estimated 370,000 inhabitants. Unfortunately, at the time of our field research, there were no lists or registers of religious leaders available that could serve as sampling frames. As an alternative, we decided in collaboration with our survey firm Pechter Polls Princeton and their local partner to select religious leaders on the basis of a catch-all principle. In total, our sample comprises 102 religious leaders (including imams, bishops, pastors, and deacons) from Juba, and thus represents a ratio of 1 religious leader per 3,627 inhabitants. While our sample probably failed to cover every last religious leader in Juba, we are confident that it does a sufficiently good job of representing the majority of religious leadership within the South Sudanese capital. For the purpose of cross-validating the representativeness of our sample, we compared the per capita coverage per religious leader with figures for Catholic priests per Catholic believer in other sub-Saharan African nations. Drawing on figures published on the Catholic-hierarchy.org website, we calculate that in the DR Congo, one Catholic priest serves 6,800 Catholic believers. In Nigeria this figure is 4,000 , in Kenya 4,200 , in Cameroon 3,050, and in Ghana 2,500. In very rough terms, we are able to say that the inhabitants-toreligious leaders ratio in our Juba sample presents a reasonable figure for convincingly claiming that we have likely caught the majority of religious leaders living in Juba. 
We included exclusively Muslim and Christian religious leaders. The following cross-table below (Table 1) describes our total sample of 102 religious leaders along three key dimensions: religious affiliation, gender, and age group. It shows that 87 respondents were Christian, of which only 7 were women, and 15 were Muslim. Although these figures suggest a bias toward male, Christian religious leaders, we believe that our sample reasonably represents the real distribution of religious leaders in Juba (and elsewhere). As mentioned above, 6.2 percent of the South Sudanese population are estimated to be Muslim, with possibly higher numbers in the major towns where international trade is often in the hands of Muslims. Hence, around 15 percent Muslim respondents appears to be an equitable figure. With regard to women as Christian religious leaders, we hold that 7 percent is probably a quite realistic share as well.

Respondents were interviewed by local enumerators, as the presence of white, Western foreigners would probably have had an effect on the contents of interviews. Local partners reported no irregularities during the interviews. The questionnaire used comprises twenty-eight items divided into demographic and biographical sections, as well as ones on attitudes toward religious affairs as well as toward conflict (see Table 1A in the online appendix at http://prq.sagepub.com/supplemental/). Some items combine attitudes toward conflict and religion. We will elaborate on detailed items in the questionnaire in the next subsection, wherein we also outline the operationalization of our main variables.

\section{Operationalization of Key Variables}

We decided to indirectly ask the respondents about their attitudes toward violence, the dependent variable. Respondent were given two hypothetical situations in which either Christians or Muslims riot as a reaction to a religiously charged insult ("Christians riot as a reaction to an insult against Jesus"; "Muslims riot as a reaction to an insult against Prophet Muhammad"). The questionnaire also included a similar pair of questions in which there were explicitly peaceful protests instead of riots. Respondents could assess their approval for all of these (four) hypothetical situations on a scale ranging from 1 to 7 , where 7 meant that the riots/protests were understandable and 1 that they were not at all justifiable. We have to clarify here that we asked about a hypothetical situation, not about actual rioting in South Sudan, as - to the best of our knowledge - no faith-related riots have occurred in South Sudan. The indirect manner of the questioning was intentional, and is a standard approach for addressing and avoiding the distortive effects that arise due to social desirability. Direct questions about one's personal readiness to engage in violence are not considered valid items in such surveys (e.g., Tourangeau and Yan 2007).
Table I. Cross-Tabulation of Key Characteristics of the Sample $(N=102)$.

\begin{tabular}{lccccc}
\hline & \multicolumn{4}{c}{ Religious affiliation and gender } \\
\cline { 2 - 3 } & \multicolumn{2}{c}{ Christian } & & \multicolumn{2}{c}{ Muslim } \\
\cline { 2 - 3 } \cline { 5 - 6 } Age & Male & Female & & Male & Female \\
\hline Under 18 & - & - & & - & - \\
18-25 & 1 & 1 & & - & - \\
$26-35$ & 15 & 2 & & 1 & - \\
$36-45$ & 33 & 1 & & 5 & - \\
Above 45 & 31 & 3 & & 9 & - \\
Total & 80 & 7 & & 15 & - \\
\hline
\end{tabular}

On the basis of this information, we created three variables for the attitude toward violence harbored. The main dependent variable combines the extent of support for both situations (total_riot). Two other variables take into account the religious identity of the respondent and whether it is Christians or Muslims who are rioting. The second dependent variable (own_riot) captures to what extent respondents approved of riots when their "own" religious groups were insulted. For instance, we asked whether Christian clerics supported rioting as a reaction to an offense against Jesus. The third variable measures to what extent respondents approved of riots by another religious group (other_riot). Three equivalent variables were created for the peaceful protests.

In descriptive terms a majority of respondents completely disapproved of riots- 57 percent, 64 percent, and 61 percent, respectively, for the three variables discussed above. However, the dependent variable nevertheless meaningfully distinguishes the respondents from each other: Between 16 percent and 18 percent of respondents signaled their understanding when people riot, with between 9 percent and 13 percent giving the highest possible level of approval for such reactions. The distribution of these and all following variables is presented in the violin plots of Figure 1 below. $^{3}$

As the questionnaire contains many different items (see Appendix Table A2) we reduced the number of independent variables to include only the most important ones. Key demographic and biographical variables such as age, gender (female), and level of education (education) were included to measure $\mathrm{H} 1$ and $\mathrm{H} 2$. We also included two variables on whether respondents had previously spent some time abroad (studied/lived abroad) or had had personal experience with violence, to operationalize $\mathrm{H} 2$ (personal violence). The latter was captured through two questions. One asked for personal threats or attacks directed toward the respondent (none, once, more than once), the other whether any family members had previously been killed. We combined the two scores in a simple additive logic, resulting in a value between 0 and 


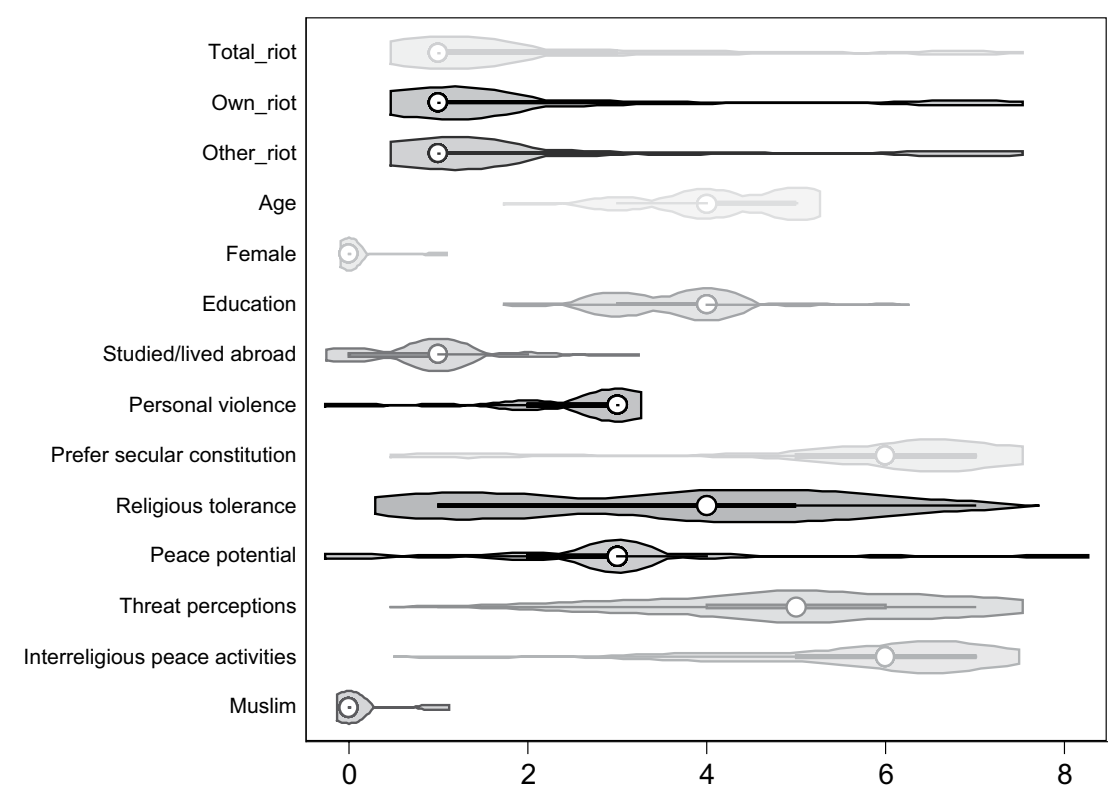

Figure I. Violin plots of variables.

For each variable, the violin plot shows the range of values (left-right end points), the median (white dot), and the distribution of the values. For instance, the first variable total_riot has a minimum value of $I$ and a maximum of 7 ; its median lies at I, and it is positively skewed. The visual presentation needs to be read with caution, however. Although total_riot (and other variables) appears to have hardly any variation, at least visually, the actual values are more diverse (see discussion in the text).

3. Zero indicates that neither the respondent nor his or her family members were attacked or threatened, 3 means that a family member was killed and the respondent was threatened more than once. ${ }^{4}$

For testing H3 (religious attitudes), we used a combination of innovative items on religious attitudes. Secularism (prefer secular constitution) was measured through the level of approval given to the statement, "School curricula and the constitution should mention religion respectfully but otherwise be secular and not give priority to any specific religious viewpoint over another." Religious tolerance toward other faiths was captured through several different statements (additionally identified by factor analysis) on how a democratic society should treat religious deviance such as atheism or polytheism or membership in minority religious groups. We also asked to what extent religious leaders have contributed to peace in a number of particular South Sudanese conflicts, ${ }^{5}$ as we assume that people who see a peace potential in religion will also be less tolerant of faith-based violence. The fourth measure of $\mathrm{H} 3$ was threat perceptions vis-à-vis other religious groups. Respondents were asked to imagine a situation in which several drunk young men were crossing their path. The item included several options regarding the religious social identity of these men, including Christian, nonbeliever, or Muslim. Respondents then had to assess to what extent they would be scared of these individuals, also estimating their likely level of fear for each group separately.
H4 tests the role of interreligious peace activities in mitigating violence. We had several items that covered this eventuality. One direct question on experience with interreligious, ecumenical training had to be dropped as it did not meaningfully distinguish the respondents from each other-almost all of those interviewed had undergone such training. Instead, we again used the approval for hypothetical situations such as joint demonstrations of religious groups for democracy and peace. To test $\mathrm{H} 5$ on Muslim versus Christian identity, we simply employed the respondent's self-reported - and mostly self-evidentreligious identity (Muslim).

\section{Estimation Technique}

Our dependent variables are seven-point Likert-type scaled measures of attitudes to faith-based violence. Such measures can be treated as interval-scaled variables, and we therefore use a linear model. ${ }^{6}$ Since we employ crosssectional data and cannot exclude problems of reverse causality, our approach has limitations regarding its potential to find causal relationships in the strict sense. We ran several robustness checks using alternative models, samples, and specifications; these checks we describe in the course of this subsection. In addition, Table A14 in the online appendix shows the response patterns between the dependent variable total_riot and the independent variables. 
Table 2. OLS Regression Results on Support for Faith-Based Riots.

\begin{tabular}{|c|c|c|c|c|c|c|c|c|c|}
\hline & (I) & $(2)$ & (3) & (4) & (5) & (6) & (7) & $(8)$ & (9) \\
\hline \multirow[t]{2}{*}{$\mathrm{HI}:$ Age } & -0.0312 & -0.0490 & 0.0591 & -0.148 & -0.0276 & -0.0308 & -0.207 & -0.0312 & -0.148 \\
\hline & $(0.326)$ & $(0.3 I I)$ & $(0.298)$ & $(0.326)$ & $(0.326)$ & $(0.330)$ & $(0.316)$ & $(0.288)$ & $(0.280)$ \\
\hline \multirow[t]{2}{*}{ HI: Female } & 0.0788 & 0.286 & 0.0931 & 0.381 & 0.109 & 0.170 & 0.367 & 0.482 & 0.634 \\
\hline & $(0.824)$ & $(0.587)$ & $(0.855)$ & $(0.794)$ & $(0.806)$ & $(0.837)$ & $(0.791)$ & $(0.669)$ & $(0.580)$ \\
\hline \multirow[t]{2}{*}{$\mathrm{H} 2$ : Education } & 0.202 & 0.205 & 0.170 & 0.334 & 0.215 & 0.214 & 0.0537 & $0.285^{\prime}$ & 0.108 \\
\hline & $(0.335)$ & $(0.328)$ & $(0.330)$ & $(0.296)$ & $(0.327)$ & $(0.330)$ & $(0.248)$ & $(0.277)$ & $(0.208)$ \\
\hline \multirow[t]{2}{*}{ H2: Studied/lived abroad } & -0.0822 & -0.246 & -0.102 & 0.211 & 0.0316 & -0.0621 & 0.289 & 0.137 & 0.357 \\
\hline & $(0.478)$ & $(0.418)$ & $(0.437)$ & $(0.457)$ & $(0.482)$ & $(0.485)$ & $(0.368)$ & $(0.383)$ & $(0.303)$ \\
\hline \multirow[t]{2}{*}{ H2: Personal violence } & -0.160 & -0.0285 & 0.0345 & -0.193 & -0.102 & -0.0868 & -0.208 & 0.163 & 0.145 \\
\hline & $(0.185)$ & $(0.172)$ & $(0.209)$ & $(0.200)$ & $(0.192)$ & $(0.188)$ & $(0.191)$ & $(0.205)$ & $(0.202)$ \\
\hline \multirow[t]{2}{*}{ H3: Prefer secular constitution } & & $-0.400 * *$ & & & & & & $-0.305^{\dagger}$ & $-0.332 *$ \\
\hline & & $(0.146)$ & & & & & & $(0.156)$ & $(0.140)$ \\
\hline \multirow[t]{2}{*}{ H3: Religious tolerance } & & & $-0.276^{*}$ & & & & & $-0.334 * *$ & $-0.26 I^{* *}$ \\
\hline & & & $(0.109)$ & & & & & $(0.103)$ & $(0.0927)$ \\
\hline \multirow[t]{2}{*}{ H3: Peace potential } & & & & $-0.416 * *$ & & & & -0.356 ** & -0.146 \\
\hline & & & & $(0.125)$ & & & & $(0.135)$ & $(0.106)$ \\
\hline \multirow[t]{2}{*}{ H3: Threat perceptions } & & & & & -0.177 & & & -0.205 & $-0.275^{\dagger}$ \\
\hline & & & & & $(0.149)$ & & & $(0.156)$ & $(0.147)$ \\
\hline \multirow[t]{2}{*}{ H4: Interreligious peace activities } & & & & & & -0.141 & & 0.101 & 0.0506 \\
\hline & & & & & & $(0.166)$ & & $(0.198)$ & $(0.203)$ \\
\hline \multirow[t]{2}{*}{ H5: Muslim } & & & & & & & $2.980 * * *$ & & $2.58 I^{* * * *}$ \\
\hline & & & & & & & $(0.676)$ & & $(0.564)$ \\
\hline \multirow[t]{2}{*}{ Constant } & 2.167 & $4.319 *$ & 2.452 & $3.217^{\dagger}$ & 2.751 & 2.736 & $2.748^{\dagger}$ & $5.315^{* *}$ & 5.796 **** \\
\hline & (I.879) & $(2.045)$ & $(1.785)$ & $(1.730)$ & (1.958) & (2.039) & (1.593) & $(1.75 \mathrm{I})$ & (1.338) \\
\hline Observations & 97 & 97 & 97 & 97 & 97 & 97 & 97 & 97 & 97 \\
\hline Adjusted $R^{2}$ & -.042 & .080 & .019 & .074 & -.034 & -.044 & .232 & .225 & $.41 \mathrm{I}$ \\
\hline
\end{tabular}

Robust standard errors in parentheses. OLS = ordinary least squares.

$\dagger_{p}<.10 . *_{p}<.05$. ** $p<.01$. *** $p<.001$.

\section{Results}

The results of the multivariate ordinary least squares (OLS) regression can be detected from Table 2. The first finding is that we have almost no support for $\mathrm{H} 1$ (demography) which assumes that younger males are more likely to support violence. Although being older consistently reduces the likelihood of having a pro-violence attitude, it never reaches conventional levels of statistical significance. Being female is positively associated with support for violence. The reason for this result is probably partly rooted in the peculiarities of the sample or of the group as such, as it-inevitably — included many more older men and fewer women, only seven, and few young men. Only two respondents were below twenty-five years of age.

H2 (biography) does not receive more support than H1 (demography) either. Neither experience outside the country nor higher levels of education or personal experience with violence explain the divergence in views on the legitimacy of riots. This low explanatory power might again be explained by the specifics of the sample, as only 13 percent were never attacked or threatened and only 18 percent reported that no family members had previously been killed. H3 (attitudes) receives substantial but uneven support. All four measures - secularism, tolerance, threat perceptions, and beliefs in the peace potential-are significant in at least one model, and all reduce the likelihood of giving support to faith-based violence. Two variables - support for a secular constitution and tolerance toward other faiths - stand out. The substantive effect of both variables is considerable. A one unit change on the seven-point Likert-type scale is associated with up to a 0.4 decrease on the same-scaled dependent variable. Apparently, disapproval of violence in religious affairs is strongly correlated to less extremist views in other areas. Leaders who accept that their faith is no better than that of others are also less likely to assume that violence can be used as a legitimate response to a religious insult.

H4 (interreligious activities), meanwhile, must be rejected. Participating in more interreligious peace activities does not reduce the individual's propensity for violence. Perhaps interreligious activities cannot help in cases with extreme violence (in the Sudanese civil war) until much more time goes by. Finally, H5 (religious identity) enjoys substantial support. According to our results, Muslim clerics are much more likely to accept the use of violence than their Christian counterparts are. The dichotomous variable Muslim is significant at the 0.1 percent level and its substantive effect is large. Keeping other variables constant, being a Muslim religious leader 
is associated with a 2.6 points higher score on the dependent variable. It is also worth noting that the adjusted $r^{2}$ statistic increases considerably from models 8 to 9 in Table 1 when introducing the Muslim variable, thus increasing the explanatory power of the model.

This result has to be put into perspective. We do not want to give the misleading impression that we think that Islam is by nature more disposed to violence than other faiths are. As already noted above, we do not believe in essentialist notions of particular faiths. Islam, as with Christianity or other faiths, consists of huge and dynamic multifaceted clusters of ideas and people behind them. These faiths are not distinct and clear-cut phenomena. All religious and theological ideas are subject to interpretation and, dependent on specific circumstances, at times violence may have a bigger role in and for some religious groups than it does in and for others.

Applied to Islam in South Sudan, our result comes then as little surprise. Islam in previously unified Sudan had a pronounced fundamentalist streak to it; the hypothetical riots described in our questionnaire had actual precedents. As discussed, the Islamist regime in Northern Sudan did actually previously organize riots in response to the Mohammed cartoons. Moreover, most of the Muslim leaders in South Sudan have a Northern background. As also noted above, Muslims are a minority in South Sudan and Northern Muslims were the adversaries of Christian-Animist Southerners in the civil war in then unified Sudan. As a result, Muslim clerics might be more anxious and hence more liable to support violence in reaction to an offense.

As our dependent variables were positively skewed and even after various transformations their residuals did not exactly feature a normal distribution, we ran additional logistic regressions for the robustness of the results. For this purpose, we transformed the dependent variables into dummies where 1 captures all those respondents with a value higher than 6 -in other words, all those highly supportive of faith-based violence (maximum level). Results are available in the online appendix. By and large, the results correspond to the OLS regressions (see Appendix Tables A3 and A13). The preference for a secular constitution is negatively significant in all models and even increases its statistical significance in the full model. Religious tolerance has a negative effect and is statistically significant, and therefore, is also robust when compared with the OLS results. The explanatory power of the binary variable Muslim remains robust as well. However, there are a few differences. In some, but not all, models of the logistic regressions in Table A3, personal violence increases the support for riots and is statistically significant. The variable peace potential, partially significant in the OLS models, loses its statistical significance.
We also performed tests with alternative operationalizations of the dependent variable (see Table 3 and Appendix Tables A4 to A7). We first took a look at how people assess rioting by their own group or another group. With a grain of salt, these results confirm the findings from the main variable total_riots. $\mathrm{H} 1, \mathrm{H} 2$, and $\mathrm{H} 4$ on demography, biography, and interreligious activities cannot be supported, while $\mathrm{H} 3$ and $\mathrm{H} 5$ on religious attitudes and religious identity receive strong support. With $\mathrm{H} 3$, it is religious tolerance that is consistently significant; secular views have no significant influence on own_riots. In general, there is evidence for an in-group bias. Interestingly, Muslims support riots not only by their own kind but also almost equally by Christians.

The picture changes when we take a look at peaceful protests. As shown by Table 3, H1 and H2 (demography and biography) are rejected again while secularism is no longer significant. Religious tolerance changes the signthat is, the direction of the relationship. More tolerance yields more empathy for peaceful protest, although this is only significant for peaceful protests in general and protests by one's own group; support for protests by others is less pronounced. Threat perceptions vis-à-vis other groups also change the direction of the relationship and become positive, but remain insignificant. Interreligious peace activities become robustly significant, regardless of who is protesting. Apparently, interreligious activities increase understanding regarding peaceful protest (but not riots). Interestingly, the Muslim dummy only barely reaches statistical significance in explaining understanding for their own kind's peaceful protests, but not for peaceful protests in general or for other groups. If anything, Muslim leaders do apparently appreciate peaceful protest but only as relates to their own group.

Moreover, we performed an additional test with a sample of sixty-six laymen, all active in their religious communities, who were also asked to fill out the questionnaire. We admit that the sample is small and respondents were less carefully selected than the clerics were. However, the results are remarkably different compared with the results for the sample with the leaders (see Table A9 in the online appendix). In particular, we find that laymen have less different attitudes toward the support of peaceful and violent protest. When laymen support secularism and religious tolerance, they equally tend to reject violent and peaceful protest while secularly oriented and tolerant religious leaders support peaceful protest and only reject riots. In addition, the effect of a Muslim identity on the support of riots (and protest) is much weaker for laymen than for leaders - supporting the view that the Northern origin of most of the Muslim clerics may explain why they tend to support violence.

These preliminary findings have important theoretical implications and are, at least, compatible with the idea 
Table 3. Regression Results on Positive Attitudes toward Faith-Based Riots and Peaceful Protests.

\begin{tabular}{|c|c|c|c|c|c|c|}
\hline & (I) & (2) & (3) & (4) & (5) & (6) \\
\hline & total_riot & own_riot & other_riot & total_peaceful & own_peaceful & other_peaceful \\
\hline HI: Age & -0.148 & -0.183 & -0.113 & -0.339 & -0.334 & -0.343 \\
\hline & $(0.280)$ & $(0.290)$ & $(0.287)$ & $(0.260)$ & $(0.277)$ & $(0.269)$ \\
\hline HI: Female & 0.634 & 0.975 & 0.294 & -1.121 & -0.924 & $-1.318^{\dagger}$ \\
\hline & $(0.580)$ & $(0.699)$ & $(0.524)$ & $(0.765)$ & $(0.854)$ & $(0.724)$ \\
\hline H2: Education & 0.108 & 0.134 & 0.0823 & -0.0959 & -0.121 & -0.0704 \\
\hline & $(0.208)$ & $(0.196)$ & $(0.258)$ & $(0.323)$ & $(0.349)$ & $(0.333)$ \\
\hline H2: Studied/lived abroad & 0.357 & 0.271 & 0.443 & -0.112 & -0.299 & $0.074 I$ \\
\hline & $(0.303)$ & $(0.306)$ & $(0.36 \mathrm{I})$ & $(0.306)$ & $(0.274)$ & $(0.427)$ \\
\hline $\mathrm{H} 2$ : Personal violence & 0.145 & $0.409^{\dagger}$ & -0.120 & 0.195 & 0.368 & 0.0222 \\
\hline & $(0.202)$ & $(0.210)$ & $(0.247)$ & $(0.268)$ & $(0.319)$ & $(0.287)$ \\
\hline H3: Prefer secular Constitution & $-0.332 *$ & -0.193 & $-0.47 \mid * *$ & -0.121 & -0.0129 & -0.229 \\
\hline & $(0.140)$ & $(0.14 I)$ & $(0.161)$ & $(0.146)$ & $(0.162)$ & $(0.155)$ \\
\hline H3: Religious tolerance & $-0.26 I^{* *}$ & $-0.248 * *$ & $-0.275^{* *}$ & $0.218^{\dagger}$ & $0.236^{*}$ & 0.200 \\
\hline & $(0.0927)$ & $(0.09 \mid 2)$ & $(0.104)$ & $(0.1 I 2)$ & $(0.112)$ & $(0.122)$ \\
\hline H3: Peace potential & -0.146 & -0.140 & -0.152 & -0.291 & -0.247 & $-0.336^{\dagger}$ \\
\hline & $(0.106)$ & $(0.103)$ & $(0.126)$ & $(0.18 I)$ & $(0.174)$ & $(0.200)$ \\
\hline H3: Threat perceptions & $-0.275^{\dagger}$ & $-0.286^{\dagger}$ & -0.264 & 0.140 & 0.0946 & 0.186 \\
\hline & $(0.147)$ & $(0.146)$ & $(0.175)$ & $(0.169)$ & $(0.172)$ & $(0.200)$ \\
\hline H4: Interreligious peace activities & 0.0506 & -0.0155 & 0.117 & $0.592 * *$ & $0.508^{*}$ & 0.676 ** \\
\hline & $(0.203)$ & $(0.220)$ & $(0.215)$ & $(0.195)$ & $(0.229)$ & $(0.204)$ \\
\hline H5: Muslim & $2.581 * * *$ & $3.170 * * *$ & $1.993 * * *$ & 0.748 & $1.291^{\dagger}$ & 0.204 \\
\hline & $(0.564)$ & $(0.622)$ & $(0.578)$ & $(0.6 \mid 3)$ & $(0.658)$ & $(0.661)$ \\
\hline Constant & $5.796 * * *$ & $4.698 * *$ & $6.895 * * *$ & 2.685 & 2.337 & 3.033 \\
\hline & $(1.338)$ & (1.387) & $(1.622)$ & (I.775) & (1.984) & $(1.969)$ \\
\hline Observations & 97 & 97 & 97 & 97 & 97 & 97 \\
\hline Adjusted $R^{2}$ & .411 & .412 & .376 & .262 & .295 & .192 \\
\hline
\end{tabular}

Robust standard errors in parentheses.

$t_{p}<.10 . * p<.05 . * * p<.01 . * * * p<.001$

that the views of religious leaders as regards peace and violence do not simply reflect those of their followersand hence must be analyzed separately to understand processes of mobilization of "ordinary" members of religious and other communities (see Djupe and Gilbert 2003). ${ }^{7}$

In sum, the robustness checks increase our confidence in the validity of our main results. Pro-violence views are closely related to other religious attitudes, mainly tolerance toward others faiths; religious identity also plays a role but certainly only in connection with specific historic contexts; determinants for a violent or peaceful reaction to religious offenses are distinct, confirming that choices to back peaceful or violent protests follow different logics respectively. We also have preliminary evidence that the views of leaders and followers are not identical.

\section{Conclusion}

Religious leaders likely play a key role in mobilizing believers as they can call for peace or instigate violence. But what makes religious leaders support either peace or violence? Drawing on a survey poll of 102 religious leaders in Juba, South Sudan, this paper is virtually the first attempt to study this topic in a more systematic manner in a developing country. The paper has analyzed when and why some religious leaders are liable to support faithbased violence - measured as the approval of riots as a reaction to an offense to Mohammed and/or Jesus - while others are not. The paper has looked at a unique combination of classical determinants of support for violence such as age, gender, education, and one's personal experience with violence, as well as a wide range of pertinent religious attitudes and behaviors such as tolerance toward other faiths, threat perceptions vis-à-vis other groups, as well as interreligious activities.

Our results suggest that the support for faith-based violence is largely independent of individual demographic and biographical determinants but is closely related to other religious attitudes. Those leaders who embrace secularism and are tolerant of other faiths reject religion-based violence - and vice versa. Surprisingly, interreligious activities do not reduce the support for violence but do at least increase understanding for peaceful protest (by others). Other demographic and biographical determinants do not make a difference either, with one exception: Muslim clerics seem to be more ready to support faith-based violence, probably because of two specific contextual reasons rather than by a notion of Islam 
being inherently violent. First, radical Islamism is prominent in Northern Sudan, and most of the clerics have a Northern biographical background. Second, Muslims form a minority in the country and minority status leads to threat perceptions which make a fertile ground for radical attitudes - as we know from many other religious and ethnic minorities, also in Western countries.

Generally, however, the study supports the idea that pro-violence attitudes among religious leaders mainly depend on personal convictions. The paper also shows that their support for peaceful or violent protest follow different logics respectively. We have preliminary evidence that the views of leaders and laymen differ regarding the support of faith-based violence.

While our results are only a first step, we claim that our findings matter beyond the case of South Sudan: First, the paper contributes in several ways to the study of religion and violence in general. Religious leaders are important for conflict dynamics, and a survey-based study of religious elites' attitudes toward (faith-based) violence in the context of a developing country had been lacking. Previous studies focus on ordinary believers and tolerance rather than leaders and violence. The paper also employs a unique combination of partially innovative measures of a wide range of religious attitudes and other characteristics. Some results run counter previous findings and expectations - for instance, that interreligious activities are not a universal remedy for problematic interfaith relations.

Second, our study is relevant beyond a specialized debate on religion and conflict. As already argued, religion has apparently become more important for conflict in general. Some works estimate that around half of all armed conflicts have religious overtones (e.g., Basedau, Pfeiffer, and Vüllers 2014; Svensson 2007). As a consequence, the religion-violence nexus forms an important part in the field of peace and conflict studies per se. Moreover, some of our study's implications are important for research on processes of political mobilization in general (see Fox 2013). Differences between the support for violent and peaceful protest as well as differences between the attitudes of leaders and ordinary group members clearly matter beyond the role of religious leaders in mobilization and conflict processes.

Despite the pioneering nature of this study, its significant results, and implications, however, many caveats and imperatives for future research remain: First, although it was not our intention to write an article about the role of religion in South Sudan, the results may still need further contextualization. Second, our sample may have certain shortcomings, specifically as there is a strong Christian bias and some results may stem from South Sudanese peculiarities. Therefore, our findings need to be replicated in other settings and with larger samples. The latter, if possible, should be based on a more solid sampling strategy in conventional terms, regardless of how difficult this might be in practice in developing countries like South Sudan.

Other imperfections of our survey and questionnaire can also be avoided in future research: for instance, scholars should include items that directly capture competition between religious leaders. Such competition is a chief variable in the literature but was not measured in this study. It would be interesting to compare attitudes of religious and political leaders. The role of institutions also deserves further scrutiny. Recent evidence suggests that local religious institutions may have a pacifying effect (De Juan, Pierskalla, and Vüllers 2015). We have also seen that our rather crude dummy variable for Muslim religious leaders explained a substantial part of the variance. Disaggregating the Muslim/Christian dichotomy into more nuanced categories and dimensions may yield further worthwhile - and more accurate - insights.

Generally, the relationship between leaders and followers of communities deserves closer inspection. We have assumed that leaders influence supporters. The reverse may hold true as well; most likely, complex interactions occur that deserve further inspection. In that regard, structural equation models could be used to improve the analysis. We also have to think about the difference between attitudes and actual action, in particular, the specific circumstances that transform thoughts into deed. In sum, there are huge opportunities for better understanding violence awaiting researchers in this field and the study of conflict in general. The preferences and behaviors of religious leaders matter for violence and mobilization processes, and it is extremely important to know as much about them as possible.

\section{Supplemental Material}

Supplementary material and replication data to this article can be viewed at http://www.giga-hamburg.de/en/data/whenreligious-leaders-support-faith-based-violence. The usual caveat applies.

\section{Acknowledgment}

We are indebted to Alexander De Juan, Ingrid Breilid, three anonymous reviewers, and the journal's editors, especially Jason Maloy, for useful comments. A number of additional valuable comments were made when earlier drafts of the paper were presented in Oslo and in New Orleans. Anna Wolkenhauer and Christian Ederer provided indispensable research assistance.

\section{Declaration of Conflicting Interests}

The author(s) declared no potential conflicts of interest with respect to the research, authorship, and/or publication of this article. 


\section{Funding}

The author(s) disclosed receipt of the following financial support for the research, authorship, and/or publication of this article: The authors would like to thank the German Ministry of Development Co-operation (Project number: 201005 850) as well as the Research Council of Norway (Project number: $217995 /$ V10) for generous financial support.

\section{Notes}

1. "Religion" is notoriously difficult to define. According to Toft $(2007,99)$, definitions "typically include some or all of the following elements: a belief in a supernatural being (or beings); . . a view that explains both the world as a whole and a person's proper role in it; a code of conduct in line with that worldview; and, a community bound by its adherence to these elements."

2. The major civil war that broke out in December 2013 is said to have been fought along ethnic lines - in other words, between Dinka (government) and Nuer (rebels; Koos and Gutschke 2014).

3. Because of space restrictions, descriptive summary statistics are shown in Table A1 in the online appendix (http:// prq.sagepub.com/supplemental/). Furthermore, we show plots of religious leaders' opinions on faith-based violence (total_riot) and peaceful protests (total_peaceful) disaggregated by religious affiliation, gender, and age group (see Figures A1 and A2 in the online appendix.

4. We provide a cross-tabulation of the two constituent variables in Table A11 in the online appendix. Seventy-four (out of the ninety-seven) respondents have lost a family member as well as experienced violence personally. In Table A12, we test our standard regression model with all three violence variables (personally attacked, family member killed, and the index variable). In none of these models are any of these variables significant. The results remain robust across all three models.

5. These conflicts were between the Dinka and the Murle; between the South Sudanese government and the Lord's Resistance Army (LRA); with the Arrow Boys; in Upper Nile; in Abyei; in Wun Lit between the Dinka and Nuer; between Murle and Nuer in Jonglei state; and between North and South Sudan.

6. We agree that with 102 respondents, our sample is relatively small, however not unusually small. The sample size is largely related to the specific target population, that is, clerics in Juba. The results need to be interpreted cautiously.

7. We performed two more robustness checks with ethnicity (dummy with Dinka vs. other groups) and an interaction term of gender and age. Both are insignificant and do not alter our other results (see Appendix Tables A8 and A10).

\section{References}

Adorno, Theodor W., Else Frenkel-Brunswik, Daniel J. Levinson, and R. Nevitt Sanford. 1950. The Authoritarian Personality. New York: Harper and Brothers.

Agwanda, Titus, and Geoff Harris. 2009. "People-to-People Peacemaking and Peacebuilding: A Review of the Work of the New Sudan Council of Churches." African Security Studies 18 (2): 42-52.

Akbaba, Yasemin, and Zeynep Taydas. 2011. "Does Religious Discrimination Promote Dissent? A Quantitative Analysis." Ethnopolitics 10 (3-4): 271-95.

Appleby, Scott. 2000. The Ambivalence of the Sacred: Religion, Violence and Reconciliation. Lanham: Rowman \& Littlefield.

Basedau, Matthias, Birte Pfeiffer, and Johannes Vüllers. 2014. "Bad Religion? Religion, Collective Action and the Onset of Armed Conflict in Developing Countries." Journal of Conflict Resolution. Published electronically July 23.

Bellair, Paul E., and Thomas L. McNulty. 2009. "Gang Membership, Drug Selling, and Violence in Neighborhood Context." Justice Quarterly 26(4):644-669.

Black, David S., Steve Sussmann, and Jennifer B. Unger. 2010. "A Further Look at the Intergenerational Transmission of Violence: Witnessing Interparental Violence in Emerging Adulthood." Journal of Interpersonal Violence 25 (6): 1022-42.

Breidlid, Ingrid Marie, and Anders Øien Stensland. 2011. "The UN Mission and Local Churches in South Sudan: Opportunities for Partnerships in Local Peace-Building." Conflict Trends 3 (2011): 33.

Canetti, Daphna, Stevan E. Hobfoll, Ami Pedahzur, and Eran Zaidise. 2010. "Much Ado about Religiosity: Heightened Support for Political Violence by Failure to Conserve." Journal of Peace Research 45 (5): 575-87.

Davies, James C. 1962. "Toward a Theory of Revolution." American Sociological Review 27:5-19.

De Juan, Alexander. 2009. "A Pact with the Devil? Elite Alliances as Bases of Violent Religious Conflicts." Studies in Conflict \& Terrorism 31 (12): 1120-35.

De Juan, Alexander, Jan H. Pierskalla, and Johannes Vüllers. 2015. "The Pacifying Effects of Local Religious Institutions: An Analysis of Communal Violence in Indonesia." Political Research Quarterly 68 (2): 211-24.

Djupe, Paul, and Christopher P. Gilbert. 2003. "The Political Voice of Clergy." Journal of Politics 64 (2): 596-609.

Eisenstein, Marie A. 2006. "Rethinking the Relationship between Religion and Political Tolerance." Political Behavior 28 (4): 327-48.

Ellingsen, Tanja. 2000. "Colourful Community or Ethnic Witches' Brew? Multiethnicity and Domestic Conflict during and after the Cold War." Journal of Conflict Resolution 44 (2): $228-49$.

Fox, Jonathan. 2004. Religion, Civilization, and Civil War: 1945 through the New Millennium. Oxford: Lexington Books.

Fox, Jonathan. 2013. An Introduction to Religion and Politics: Theory and Practice. London: Routledge.

Fox, Jonathan, Patrick James, and Yitan Li. 2009. "State Religion and Discrimination against Ethnic Minorities." Nationalism and Ethnic Politics 15 (2): 189-210.

Gubler, Joshua, and Joel Sawat Selway. 2012. "Horizontal Inequality, Crosscutting Cleavages, and Civil War." Journal of Conflict Resolution 56 (2): 206-32.

Gurr, Ted. 1970. Why Men Rebel. Princeton: Princeton University Press. 
Hirschi, Travis, and Michael J. Hindelang. 1977. "Intelligence and Delinquency: A Revisionist Review." American Sociological Review 42 (August): 571-87.

Horowitz, Michael C. 2009. "Long Time Going: Religion and the Duration of Crusading." International Security 34 (2): 162-93.

Juergensmeyer, Mark. 2008. Global Rebellion. Religious Challenges to the Secular State from Christian Militias to al Qaeda. Berkeley: University of California Press.

Koos, Carlo, and Thea Gutschke. 2014. "South Sudan's Newest War: When Two Old Men Divide a Nation." GIGA Focus International Edition English 2014 (2). http://www. giga-hamburg.de/de/system/files/publications/gf_international_1402_new.pdf (accessed August 19, 2015).

Latham, Andrew A. 2011. "Theorizing the Crusades: Identity, Institutions, and Religious War in Medieval Latin Christendom." International Studies Quarterly 55 (1): 223-43.

Levitt, Heidi, and Kimberly Ware. 2006. "“Anything With Two Heads Is a Monster': Religious Leaders' Perspectives on Marital Equality and Domestic Violence." Violence Against Women 200612 (12): 1169-90.

McAdam, Doug, Sidney Tarrow, and Charles Tilly. 2001. Dynamics of Contention. New York: Cambridge University Press.

Menchik, Jeremy. 2013. "Tolerance without Liberalism. Islamic Institutions and Political Violence in 20th Century Indonesia." Unpublished diss., University of WisconsinMadison.

Montalvo, José G., and Marta Reynal-Querol. 2005. "Ethnic Polarization, Potential Conflict and Civil War." American Economic Review 95 (3): 796-816.

Hauk, Esther, and Hannes Mueller. 2015. "Cultural Leaders and the Clash of Civilizations." Journal of Conflict Resolution 59 (3): 367-400.

Pew Research Center. 2012. Religion \& Public Life. http://www. pewforum.org/2012/12/18/table-religious-composition-bycountry-in-percentages (accessed August 19, 2015).
Quinley, Harold. 1974. The Prophetic Clergy-Social Activism among Protestant Ministers. New York: John Wiley.

Rokeach, Milton. 1960. The Open and Closed MindInvestigations into the Nature of Belief Systems and Personality Systems. New York: Basic Books.

Rothchild, Zachary K., Abdollah Abdolhossein, and Tom Pyszczynski. 2009. "Does Peace Have a Prayer? The Effect of Mortality Salience, Compassionate Values, and Religious Fundamentalism on Hostility toward OutGroups." Journal of Experimental Social Psychology 45 (4): 816-27.

Rummel, Rudolph J. 1997. "Is Collective Violence Correlated with Social Pluralism?" Journal of Peace Research 34 (2): 163-75.

Sherif, Muzafer, O. J. Harvey, B. Jack White, William R. Hood, and Carolin W. Sherif. 1961. Intergroup Conflict and Cooperation: The Robbers Cave Experiment. Vol. 10. Norman: University of Oklahoma Press.

Smock, David, ed. 2002. Interfaith Dialogue and Peacebuilding. Washington, DC: U.S. Institute of Peace Press.

Svensson, Isak. 2007. "Fighting with Faith: Religion and Conflict Resolution in Civil Wars." Journal of Conflict Resolution 51 (6): 930-49.

Toft, Monica Duffy. 2007. "Getting Religion? The Puzzling Case of Islam and Civil War." International Security 31 (4): 97-131.

Toft, Monica Duffy, Daniel Philpott, and Timothy Samuel Shah. 2011. God's Century: Resurgent Religion and Global Politics. New York: W.W. Norton.

Tourangeau, Roger, and Ting Yan. 2007. "Sensitive Questions in Surveys." Psychological Bulletin 133 (5): 859-83.

Trejo, Guillermo. 2009. "Religious Competition and Ethnic Mobilization in Latin America: Why the Catholic Church Promotes Indigenous Movements in Mexico." American Political Science Review 103 (3): 323-42. 